\title{
Phytocompounds of Curcuma longa extract are more effective against bacterial biofilm than pure curcumin only: An in-vitro and in-silico analysis
}

\author{
Dibyajit Lahiri ${ }^{1,2}$, Moupriya Nag ${ }^{1}$, Soumik Dey ${ }^{1}$, Bandita Dutta $^{1}$, Sudipta Dash $^{1}$, \\ Rina Rani Ray ${ }^{2, *}$ \\ ${ }^{1}$ Dept. of Biotechnology, University of Engineering \& Management, Kolkata, West Bengal, India \\ ${ }^{2}$ Dept. of Biotechnology, Maulana Abul Kalam Azad University of Technology, Haringhata, \\ West Bengal, India \\ * Corresponding author: raypumicro@gmail.com
}

\begin{abstract}
Bioactive compounds are the group of secondary metabolites of plants that have a potent impact on antimicrobial and antibiofilm agents. Although Curcuma longa (turmeric) is well known for its antimicrobial activity, the question arises if curcumin, the primary bioactive compound is only responsible for it or the synergistic and simultaneous contribution of more than one bioactive compound are responsible for this antibiofilm efficacy. The research work aims to determine the efficacy of the extract Curcuma longa has a higher potential of antimicrobial and antibiofilm activity than the purchased curcumin and standard antibiotic. Present work was initiated with GC-MS analysis of the ethanolic extract of Curcuma longa (turmeric) and showed that in addition to curcumin, methyl palmitate de-hydro zingerone had a higher percent of availability within the extract. The in-silico studies also showed that when targeted upon Gram-positive biofilm-forming protein of Staphylococcus aureus (3TIP), curcumin alone had a binding constant value of $-6.33 \mathrm{Kcal} / \mathrm{mol}$ but showed a value of $-17.811 \mathrm{Kcal} / \mathrm{mol}$ when acted in association with Dehydrozingerone. Similarly, the binding constant's value changed from $-6.07 \mathrm{Kcal} / \mathrm{mol}$ to $23.844 \mathrm{Kcal} / \mathrm{mol}$, when Gram-negative biofilm-forming protein (3ZYB) of Pseudomonas aeruginosa was acted upon by curcumin only and in association with methyl palmitate, respectively. Lower minimum inhibitory concentration (MIC) and higher effectivity in reducing the bacterial quorum sensing (QS) activity of the turmeric extract than pure Curcumin indicated the higher antimicrobial and antibiofilm efficiency of the extract, respectively. This indicated clearly that the synergistic action of all the bioactive compounds imparts the antibiofilm activity of turmeric. The result was further confirmed by the scanning electron microscopic (SEM) studies, fluorescent microscopic studies, and FTIR analysis of EPS as well.
\end{abstract}

Keywords: Anti-biofilm; antibiotic; Curcuma longa; curcumin; synergism.

\section{Introduction}

Bacterial biofilms are the surface adhered bacterial communities with the help of extracellular polymeric substances (EPS)

(López et al., 2010). It provides an impermeable layer comprising of polysaccharides, inorganic polyanhydrides, slime, and micro capsular polysaccharides. 
It supplies required nutrients to the persistent microcolonies and prevents drug molecules' penetration into the sessile cells, thus developing multidrug resistance among the bacterial cells (Nwodo et al., 2012). Moreover, the efficacies of available antibiotics are proved to be reduced due to their high values of minimum inhibitory concentration (MIC) and minimum bactericidal concentration (MBC) (Li et al., 2017). On the other hand, the rampant use of commonly available antibiotics to remove bacterial cells has resulted in the development of antibiotic-resistant organisms (Sarkar et al., 2014). This has warranted the development of an alternate strategy for curing biofilm-related infections using ethnobotanical plants that contain bioactive compounds with remarkable antibacterial and antibiofilm properties (Kumar et al., 2013)

Turmeric (Curcuma longa), a perennial shrub with a pyriform rhizome, has been long used as a spice and is known to have antioxidant and antibacterial properties (Gupta et al., 2013, Hasan et al., 2014). The active compound present in it, the curcumin, exhibits antimicrobial property and can adversely affect biofilm by damaging the bacterial cell wall (Teow et al., 2016). The extract obtained from this ethnobotanical plant is eco-friendly and does not have any toxic impact (Alvi et al., 2018; Arshad et al., 2019). The antibiofilm action of curcumin on Streptococcus mutans, the main etiological factor behind dental caries, was tested ( $\mathrm{Li}$ et al., 2018). Literature showed that considerable work had been done depicting its bactericidal activity and its role in the inhibition of biofilm (Li et al., 2013; Tyagi et al., 2015; Charles et al., 2016; Raorane et al., 2019; Hayat \& Sabri, 2016) Although much of the report was focused on the antibiofilm activity of commercially available pure curcumin, almost no work has been done to depict turmeric extract's antibiofilm activity compared to that of pure curcumin.
In the present study, two biofilmproducing microorganisms, namely Staphylococcus aureus, and Pseudomonas aeruginosa, were considered the most common type of nosocomial organism causing surface wound infections and infections related to lungs skin, and urinary tract, respectively (Nikolić et al., 2014). These organisms were challenged with ethanolic extract of Curcuma longa, commercially purchased pure curcumin I and erythromycin, and their antibiofilm efficacies were compared through biochemical, microbial, microscopic, and spectroscopic studies. This was further substantiated using in-silico studies that were performed by designing the drug molecule and docking it with the biofilm-forming proteins of the nosocomial organisms compared to the standard antibiotic.

\section{Materials and methods}

\subsection{Microorganism}

Biofilm producing bacterial strains of Pseudomonas aeruginosa ATCC 15442 and Staphylococcus aureus ATCC 23235 used in this study were cultivated at $37^{\circ} \mathrm{C}$ on $\mathrm{LB}$ broth for 24 hours.

\subsection{Chemicals}

All the chemicals used in this study were purchased from HiMedia (Mumbai, India), SRL (India), Sigma (USA).

\subsection{Preparation of plant extract}

The ethanolic extract of the plant Curcuma longa (turmeric) was prepared by mixing $4 \mathrm{gm}$ of the plant's pulverized rhizome with 8 $\mathrm{ml}$ of $70 \%$ ethanol, followed by treatment with $700 \mathrm{uL}$ of $0.1 \mathrm{~N} \mathrm{H}_{2} \mathrm{SO}_{4}$. After 24 hours, the sample was filtered out using a cotton gauge filter, and the filtrate was stored at $0-4^{0} \mathrm{C}$. (Lahiri et al., 2018). 


\subsection{Biochemical Assay of Plant Extract}

The phytochemical assays of ethanolic extract of Curcuma longa were done for estimating total flavonoid, total phenol, hydroxyl scavenging, and hydrogen peroxide scavenging activity (Delden \& Iglewski, 1998; Debiyi \& Sofowora, 1978).

2.5. Determination of the Bioactive compounds by GC-MS

The bioactive compounds being present in the ethanolic crude extract of Curcuma longa were quantitatively determined by GC-MS (GC-Model-Trace GC Ultra; MS Model-Polaris Q, Thermo scientific; column: DBSMS manufactured by Agilent technology, Library-NIST Version 2014) well equipped capillary column (Roopashree et al., 2008). The splitless injection was performed for $1 \mathrm{~min}$ and was maintained at $50^{\circ} \mathrm{C}$ for 3 mins with a sequential variation of temperature within the system. The peaks obtained were observed using mass spectrometry and analyzed using the National Institute of Standards and Technology (NIST).

\subsection{Protein and ligand Search}

Biofilm forming proteins from the two bacterial species were identified using RCSB PDB. The chemical configurations of bioactive compounds from $C$. longa as obtained by GC-MS analysis, Erythromycin were found from PubChem Database. The ligands were converted to PDB format using Avogadro. Utilizing the Schrodinger, rotatable bonds were designated to the PDB ligands (Hossain \& Rahman, 2011).

\subsection{Protein structure preparation}

The proteins possessing X-ray crystal structures having a good resolution of about $1.5-2 \AA$ from the Protein Data Bank were selected for docking. The protein had co- crystallized ligands (X-ray ligand) in the binding site, which was removed from the binding site, and this edited protein structure (with no ligands) was saved as a new file in PDB format.

2.8. Protein-Ligand Docking using Schrodinger

The ligand-dependent protein docking calculations were performed using the Lamarckian Genetic Algorithm (LGA) method, which deals with ligands with more freedom degrees.

2.9. MIC or Minimum Inhibitory Concentration

The bactericidal and bacteriostatic effects of the bioactive compounds of $C$. longa, commercially available Curcumin I, and Erythromycin (a standard antibiotic) were detected on LB Agar spread plates at 37 0C for 24 hours for both the working strains (Morris et al., 1998).

2.10. Determination of Viability of the Biofilm forming cells by MTT Assay

The antibiofilm effect of the ethanolic extract of C. longa and pure curcumin on the working strains was checked by the microdilution method (Tang et al., 2011). Diluted plant extract or antibiotic (Erythromycin) were added with 3-[4,5dimethyl-2-thiazolyl]-2, 5 - diphenyl- 2Htetrazolium bromide (MTT dye) to quantify the viability of the bacterial cells in the presence of the challenge using ELISA plate reader (2018 GEN-NET). The percentage inhibition was determined using the following equation: [1-(A570 of the test /A570 of non-treated control) x100] (Gomes et al., 2012).

2.11. Study of the Quorum sensing of the strains 
Phytocompounds of Curcuma longa extract are more effective against bacterial biofilm than pure curcumin only: An in-vitro and

The effectivity of quorum sensing was measured spectrophotometrically (Yang et al., 2006).

2.12. Determination of Viability count of the Biofilm forming bacterial cells

The colonies of working strains were scrapped from the biofilm formed on the surface of chitin flakes and were inoculated in LB broth containing $0.1 \%(\mathrm{w} / \mathrm{v})$ of chitin flakes to re-grow for 72 hours. After adequate washing, the planktonic cells were removed, and the cultures of the working strains were treated with the required concentration of ethanolic extract of Curcuma longa, curcumin, and standard antibiotic Erythromycin in three different flasks, and the data were noted.

2.13. Estimation of the number of EPS in the presence of the plant extract

The working strains grown separately in $100 \mathrm{~mL}$ LB media with $0.1 \%(\mathrm{~W} / \mathrm{V})$ chitin flakes were centrifuged at $12000 \mathrm{rpm}$ for $15 \mathrm{mins}$ at $40 \mathrm{C}$ to break the biofilm. The pellets after proper washing with $5 \mathrm{~mL}$ PBS buffer and $2.5 \mathrm{~mL}$ of $10 \mathrm{mM}$ Tris- $\mathrm{HCl}(\mathrm{pH}$ 7.8) were mixed with $20 \mathrm{mM}$ betamercaptoethanol, and $1 \mathrm{mM}$ PMSF were sonicated at $50 \%$ power for $45 \mathrm{sec}$ for $8 \mathrm{~min}$ and was centrifuged at $12000 \mathrm{rpm}$ for $30 \mathrm{~min}$ at $40 \mathrm{C}$ followed by the addition of $10 \%$ TCA in acetone (Gandhi et al., 2017).

\subsection{Estimation of EPS content}

The EPS carbohydrate was quantified using Anthrone Method, Protein by Lowry method as adopted by Teanpaisan et al., 2016, whereas nucleic acid was measured by the existing methods (Brunk et al., 1979 and Teanpaisan et al., 2016).

2.15. Isolation and estimation of DNA, RNA and protein form working strains after providing Phyto challenge.
The genomic DNA and RNA from the challenged and unchallenged working strains were isolated and quantified using CTAB method (Meade et al., 1982; Rio et al., 2011), whereas the quantification of soluble and insoluble fractions of proteins, extracted from lysed and sonicated cell were done (Deutscher et al., 1990).

\subsection{Fluorescence Microscopy}

The biofilm formed on a glass slide after 48 hours was exposed to plant extract for 45 min. After thorough washing and drying and staining with fluorescent acridine orange dye, each slide was observed under Axioplant Fluorescence Microscope equipped with a digital camera (dxm1200, Nikon, Japan).

\subsection{Scanning Electron Microscopy (SEM):}

The effect of plant extract on biofilms formed on glass coverslips by both the working strains was visualized under a scanning electron microscope (ModelZEISS EVO-MA 10) (Brunk et al., 1979 and Teanpaisan et al., 2016).

\subsection{FTIR Analysis of Biofilm Formation}

FTIR spectrum was measured using Spectrum 100 FT-IR Spectrophotometer (Perkin Elmer). Biofilm formed on Chitin flakes for 72 hours at $37^{\circ} \mathrm{C}$ was challenged with plant extract and kept for drying at $37^{\circ} \mathrm{C}$ for 48 hours. The FTIR spectra were recorded in the spectral range of $4000-450 \mathrm{~cm}-1$ with a resolution set at $4 \mathrm{~cm}^{-1}$.

\subsection{Statistical analysis}

All the data were of sample size 5 and were represented as Mean \pm SE. 


\section{Results}

3.1. Biochemical Estimation of plant compounds

The total phenolic and flavonoid content of Curcuma longa was found to be 470.32 $\mu \mathrm{g} / \mathrm{ml}$ and $1.38 \mu \mathrm{g} / \mathrm{ml}$, respectively.

Hydrogen peroxide activity and IC50 value of the extract of Curcuma longa was found to be almost similar to that of commercial curcumin I and Ascorbic acid (standard antioxidant), which revealed the fact that the antioxidant efficacy of the phyto-extract was more or less equal to commercial curcumin I and ascorbic acid. On the other hand, the hydroxyl radical scavenging activity of raw Curcuma longa was quite lesser than that of pure curcumin I powder, probably due to the presence of various other bioactive compounds in addition to pure curcumin, making its hydroxyl radical scavenging activity less pronounced than pure curcumin I powder (Table1).

3.2. GC-MS Analysis of the bioactive compound

The GC-MS analysis of the ethanolic extract of Curcuma longa revealed the presence of nine compounds from the extract, which comprised of curcumin (R/T 30.36), zingiberene (R/T 30.74), sesquiphellandrene (R/T 31.68), benzene, l-methyl-4-(1methylethyl-) (R/T 33.45), Benzene-4methyl-1,2-diethyl (R/T 34.20), ar-tumerone (R/T 35.96), 3-buten-2-one,4-(4-hydroxy-3methoxyphenyl (R/T 39.76), hexdecanoic acid methyl ester (R/T 41.43), and pentadecanoic acid, 14-methyl-, methyl ester (R/T42.05) (Table 2).
Table 1. Hydroxyl radical scavenging activity and Hydrogen peroxide activity of ethanolic extract of Curcuma longa and pure curcumin ICInhibitory concentration.

\begin{tabular}{|c|c|c|c|c|}
\hline Sample & $\begin{array}{l}\text { Concentrati } \\
\text { on }(\mu \mathrm{g} / \mathrm{ml})\end{array}$ & $\begin{array}{l}\% \\
\text { Inhibitio } \\
n(n=5)\end{array}$ & $\begin{array}{l}\mathrm{IC}_{50} \\
(\boldsymbol{\mu g} \\
/ \mathrm{ml})\end{array}$ & $\begin{array}{l}\text { Regress } \\
\text { ion } \\
\text { Equatio } \\
\text { n }\end{array}$ \\
\hline \multicolumn{5}{|c|}{ Hydroxyl radical scavenging activity } \\
\hline \multirow{10}{*}{$\begin{array}{l}\text { Curcuma } \\
\text { longa }\end{array}$} & \multirow[t]{4}{*}{400} & \multirow{4}{*}{$\begin{array}{l}45.32 \pm 0.0 \\
2\end{array}$} & \multirow[t]{4}{*}{536} & $\mathrm{Y}=0.033$ \\
\hline & & & & $x+32.57$ \\
\hline & & & & $\mathrm{R}^{2}=0.95$ \\
\hline & & & & \\
\hline & \multirow[t]{2}{*}{500} & \multirow{2}{*}{\multicolumn{2}{|c|}{$\begin{array}{l}48.62 \pm 0.0 \\
1\end{array}$}} & \\
\hline & & & & \\
\hline & \multirow[t]{2}{*}{600} & \multirow{2}{*}{\multicolumn{2}{|c|}{$\begin{array}{l}54.35 \pm 0.0 \\
3\end{array}$}} & \\
\hline & & & & \\
\hline & \multirow[t]{2}{*}{800} & \multirow{2}{*}{\multicolumn{2}{|c|}{$\begin{array}{l}58.32 \pm 0.0 \\
5\end{array}$}} & \\
\hline & & & & \\
\hline \multirow[t]{13}{*}{ Curcumin } & \multirow[t]{5}{*}{10} & \multirow{5}{*}{$\begin{array}{l}22.36 \pm 0.0 \\
5\end{array}$} & \multirow[t]{5}{*}{49} & $\mathrm{Y}=0813$ \\
\hline & & & & $Y=0.813$ \\
\hline & & & & $x+10.89$ \\
\hline & & & & $\mathrm{R}^{2}=0.95$ \\
\hline & & & & 7 \\
\hline & \multirow[t]{2}{*}{20} & \multirow{2}{*}{\multicolumn{2}{|c|}{$\begin{array}{l}24.52 \pm 0.0 \\
1\end{array}$}} & \\
\hline & & & & \\
\hline & \multirow[t]{2}{*}{30} & \multirow{2}{*}{\multicolumn{2}{|c|}{$32.52 \pm 0.0$}} & \\
\hline & & & & \\
\hline & \multirow[t]{2}{*}{40} & $43.56 \pm 0.0$ & & \\
\hline & & 2 & & \\
\hline & 50 & $53.51 \pm 0.0$ & & \\
\hline & & 4 & & \\
\hline & Hydrogen & oxide Activ & & \\
\hline Curcuma & 4.3 & $26.34 \pm 0.0$ & 10.9 & $\mathrm{Y}=2.892$ \\
\hline longa & & 1 & & $\mathrm{X}+18.65$ \\
\hline & & & & $\left(\mathrm{R}^{2}=0.8\right.$ \\
\hline & & & & $88)$ \\
\hline & 4.7 & $32.65 \pm 0.0$ & & \\
\hline & & 1 & & \\
\hline & 5.6 & $40.35 \pm 0.0$ & & \\
\hline & & 2 & & \\
\hline & 10.2 & $47.32 \pm 0.0$ & & \\
\hline & & 5 & & \\
\hline & 12.2 & $53.65 \pm 0.0$ & & \\
\hline & & 3 & & \\
\hline Curcumin & 0.56 & $12.32 \pm 0.0$ & 8.26 & $Y=3.745$ \\
\hline & & 2 & & $\mathrm{X}+19.24$ \\
\hline & & & & $\left(\mathrm{R}^{2}=0.7\right.$ \\
\hline & & & & 97) \\
\hline & 1.2 & $26.52 \pm 0.0$ & & \\
\hline & & 1 & & \\
\hline & 3.6 & $33.54 \pm 0.0$ & & \\
\hline & & 3 & & \\
\hline & 4.2 & $44.56 \pm 0.0$ & & \\
\hline & & 3 & & \\
\hline & 10 & $52.56 \pm 0.0$ & & \\
\hline & & 4 & & \\
\hline Ascorbic & 0.56 & $10.62 \pm 0.0$ & 8.6 & $Y=4.015$ \\
\hline Ascordic & & 2 & & $X+16.29$ \\
\hline Acid & & & & $\left(\mathrm{R}^{2}=0.7\right.$ \\
\hline & & & & 70) \\
\hline
\end{tabular}


Table 2. GC-MS Analysis of the bioactive compounds in the ethanolic extract of Curcuma longa.

\begin{tabular}{|c|c|c|c|c|}
\hline SI No & $\mathbf{R} / \mathbf{T}$ & $\begin{array}{l}\text { Name of the } \\
\text { Compound }\end{array}$ & $\begin{array}{l}\text { Molecular } \\
\text { Formula }\end{array}$ & MW \\
\hline 1. & 30.36 & Curcumin & $\mathrm{C}_{22} \mathrm{H}_{18}$ & 282 \\
\hline 2. & 30.74 & Zingiberene & $\mathrm{C}_{15} \mathrm{H}_{24}$ & 204 \\
\hline 3. & 31.68 & Sesquiphellandrene & $\mathrm{C}_{15} \mathrm{H}_{24}$ & 204 \\
\hline 4. & 33.45 & $\begin{array}{l}\text { benzene, 1-methyl- } \\
\text { 4-(1-methylethyl-) }\end{array}$ & $\mathrm{C}_{10} \mathrm{H}_{34}$ & 134 \\
\hline 5. & 34.20 & $\begin{array}{l}\text { Benzene-4-methyl- } \\
\text { 1,2-diethyl }\end{array}$ & $\mathrm{C}_{10} \mathrm{H}_{34}$ & 134 \\
\hline 6. & 35.96 & ar-tumerone & $\mathrm{C}_{15} \mathrm{H}_{22} \mathrm{O}$ & 218 \\
\hline 7. & 39.76 & $\begin{array}{l}\text { 3-buten-2-one,4- } \\
\text { (4-hydroxy-3- } \\
\text { methoxyphenyl }\end{array}$ & $\mathrm{C}_{11} \mathrm{H}_{12} \mathrm{O}$ & 192 \\
\hline 8. & 41.43 & $\begin{array}{l}\text { hexdecanoic acid, } \\
\text { methyl ester }\end{array}$ & $\mathrm{C}_{17} \mathrm{H}_{34} \mathrm{O}_{2}$ & 270 \\
\hline 9. & 42.05 & $\begin{array}{l}\text { pentadecanoic } \\
\text { acid, 14-methyl-, } \\
\text { methyl ester }\end{array}$ & $\mathrm{C}_{17} \mathrm{H}_{34} \mathrm{O}_{2}$ & 270 \\
\hline
\end{tabular}

\subsection{Docking with Schrodinger}

The phytocompounds, when docked individually with biofilm-forming proteins of Gram-positive (3TIP) and Gram-negative (3ZYB) bacteria (Figure 1), showed a more excellent binding constant value than with the commonly used antibiotic, Erythromycin. Moreover, the study indicated a greater antibiofilm efficacy of the phytocompound mixture than the pure curcumin I, as they acted in synergism upon the target biofilm-forming proteins (Table 3 ).

\subsection{Viability of the Biofilm forming cells.}

The viability kinetics indicated that maximum inhibition of biofilm formation by $S$. aureus and $P$. aeruginosa were brought about by the ethanolic extract of Curcuma longa followed by commercial curcumin I powder, and erythromycin respectively (Figure. 2A), and minimum revival occurred in the extract of Curcuma longa extracttreated cells (Figure 2B). This implied that although curcumin I was a primary bioactive

compound present in turmeric extract, it was not effective in acting against the biofilmbound bacterial cells.

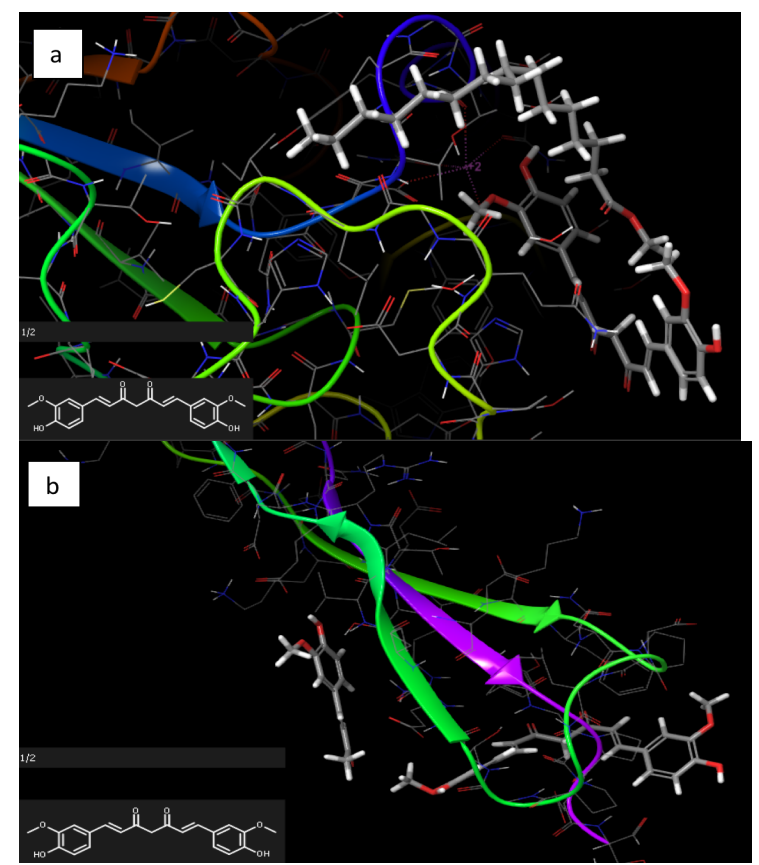

Fig. 1. (a) docking interaction of $3 Z \mathrm{ZYB}$ curcumin \& methyl-palmitate with 3ZYB protein of $P$. aeruginosa, (b) docking interaction of 3TIP with curcumin \& Dehydrozingerone of $S$. aureus.

Table 3. Binding energy value of bioactive compounds with Gram-positive and Gramnegative biofilm-forming proteins. 3ZYB and 3TIP are the biofilm-forming protein of $P$. aeruginosa and $S$. aureus, respectively.

\begin{tabular}{|c|c|c|c|}
\hline Common name & $\begin{array}{l}\text { Name of the } \\
\text { Compound }\end{array}$ & $\begin{array}{c}\text { Vs 3ZYB } \\
\text { (Kcal/mol) }\end{array}$ & $\begin{array}{l}\text { Vs 3TIP } \\
\text { (Kcal/mol) }\end{array}$ \\
\hline & Curcumin & -11.404 & -39.089 \\
\hline & Zingiberene & -9.135 & -24.168 \\
\hline & Sesquiphellandrene & -2.125 & -23.632 \\
\hline \multirow[t]{3}{*}{ p-cymene } & $\begin{array}{l}\text { benzene, l-methyl- } \\
\text { 4-(1-methylethyl-) }\end{array}$ & -2.929 & -21.323 \\
\hline & $\begin{array}{l}\text { Benzene-4-methyl- } \\
\text { 1,2-diethyl }\end{array}$ & -6.39 & -23.859 \\
\hline & ar-tumerone & -3.702 & -20.041 \\
\hline Dehydrozingerone & $\begin{array}{l}\text { 3-buten-2-one,4- } \\
\text { (4-hydroxy-3- } \\
\text { methoxyphenyl }\end{array}$ & -9.336 & -31.944 \\
\hline Methyl palmitate & $\begin{array}{l}\text { hexadecanoic acid, } \\
\text { methyl ester }\end{array}$ & -16.116 & -24.963 \\
\hline \multirow[t]{3}{*}{$\begin{array}{l}\text { Methyl 14- } \\
\text { methylpentadecanoate }\end{array}$} & $\begin{array}{l}\text { pentadecanoic acid, } \\
\text { 14-methyl-, methyl } \\
\text { ester }\end{array}$ & -7.648 & -27.775 \\
\hline & $\begin{array}{l}\text { Curcumin } \& \\
\text { Methyl palmitate }\end{array}$ & -23.844 & \\
\hline & $\begin{array}{l}\text { Curcumin \& } \\
\text { Dehydrozingerone }\end{array}$ & & -17.811 \\
\hline
\end{tabular}




\subsection{Effect of treatment on Quorum Sensing} and the viability of cells.

Since quorum sensing played a critical role in regulating biofilm formation, the concentration of Acyl homoserine lactone (AHL), the autoinducer molecule, could be used as a marker (Li et al., 2012). The extract of Curcuma longa was found to be more effective in inhibiting AHL-dependent quorum sensing (Figure 3). It was also observed that the maximum reduction of cells occurred in the presence of the ethanolic extract of Curcuma longa followed by curcumin and ethanol. The data were statistically significant $(\mathrm{p}<0.01)$

A
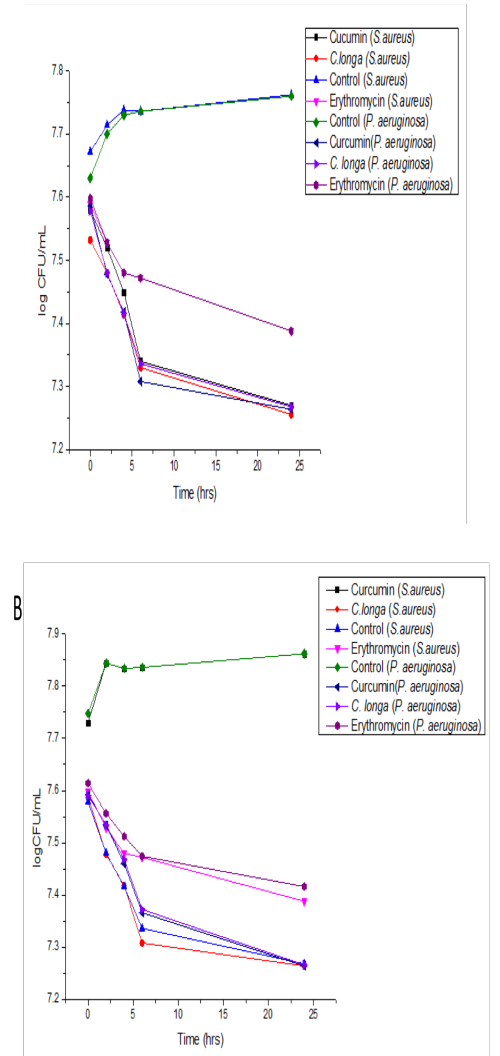

Fig. 2. A. The viability kinetics of the sessile group of $S$. aureus and $P$. aeruginosa cells after treatment with ethanolic extract of $C$. longa, commercial curcumin, and Erythromycin. B. The kinetics of the revival of treated cells of $S$. aureus and $P$. aeruginosa.

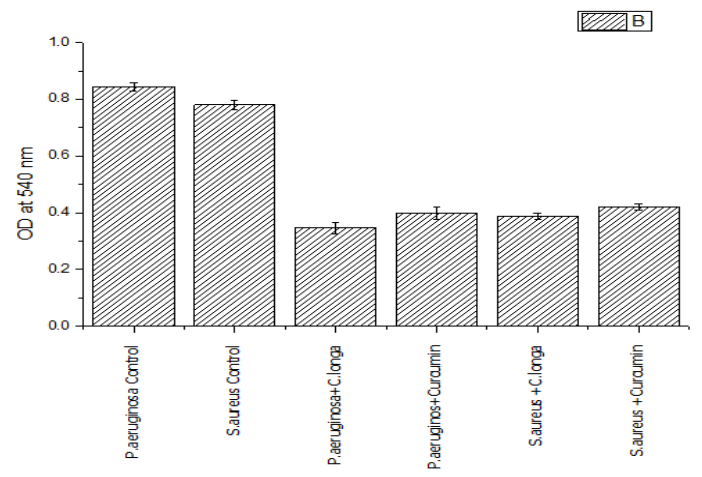

Fig. 3. Effects of treatment with ethanolic extract of Curcuma longa and commercial curcumin on the Quorum Sensing Activity $P$. aeruginosa and $S$. aureus.

3.6. Effect of treatment on the content of Extracellular Polymeric Substance (EPS)

The effect of phyto challenge on the individual components of EPS, like total carbohydrate, proteins, and nucleic acid from the biofilm formed by $S$. aureus and $P$. aeruginosa, showed a remarkable reduction in the individual contents in the presence of Curcuma longa extract (Figure 4).

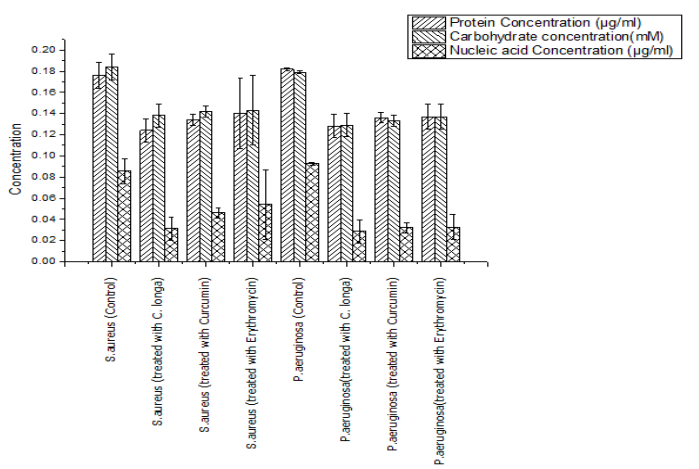

Fig. 4. Effects of treatment with ethanolic extract of Curcuma longa, commercial curcumin, and erythromycin (antibiotic) on the reduction of the protein, carbohydrate, and nucleic acid content of biofilm formed by $S$. aureus and $P$. aeruginosa.

Since the biofilm matrix proteins cells were found to be responsible for the cell surface 
adhesion and surface colonization, reduction in proteinaceous components would lead to the development of altered biofilm architecture (Fong et al., 2015). The ability of carbohydrates of EPS to bind with a suitable substrate was also found to be decreased due to herbal challenge (Ding et al., 2015). The reduced content of the EPS severely affected biofilm formation as the complex protein responsible for motility (swimming and swarming) of bacteria played a vital role in biofilm formation. The extract of Curcuma longa inhibited the microbes' motility and thus decreased the possibility of biofilm formation. After exposure to challenges, a decrease in nucleic acid concentration also indicated the loss of biofilm-forming ability since nucleic acids in EPS helped to form a three-dimensional architecture of biofilm (Ding et al., 2015).

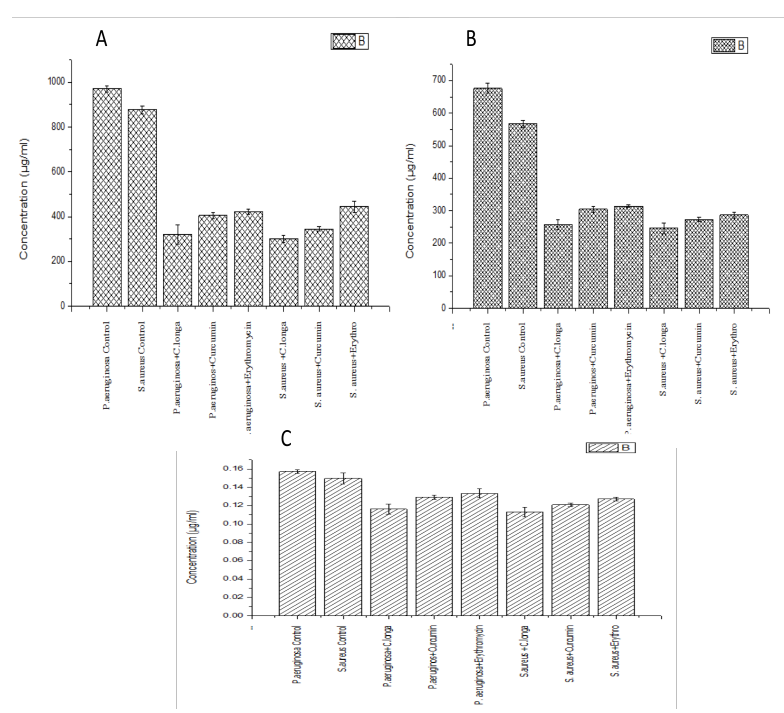

Fig. 5. Change in concentration of DNA (A), RNA (B), and total protein $(\mathbf{C})$ in $S$. aureus and $P$. aeruginosa cells after treatment with ethanolic extract of $C$. longa, commercial curcumin, and Erythromycin.
3.7. Effect of treatment on the nucleic acids and total proteins of the biofilm-forming cells.

After treatment with ethanolic extract, the biofilm-forming cells showed a marked reduction in the concentration of both DNA and RNA compared to the treatment with commercial curcumin I. Since there was a direct correlation between DNA content and bacterial growth, it could be easily concluded that the bacterial growth was seriously affected by the challenge of ethanolic extract of $C$. longa. A notable reduction in DNA content, around 652 $\mu \mathrm{g} / \mathrm{ml}$ in sessile cells of $P$. aeruginosa and around $577 \mu \mathrm{g} / \mathrm{ml}$ in $S$. aureus, was found after treatment with ethanolic extract of $C$. longa (Figure 5A). On the other hand, a decrease in RNA content revealed the inhibition of transcription and subsequent protein synthesis. As treatment with ethanolic extract of $C$. longa brought about a reduction of RNA content (Figure 5B) both in $P$. aeruginosa (about $419 \mu \mathrm{g} / \mathrm{ml}$ ) and in S. aureus (about $320 \mu \mathrm{g} / \mathrm{ml}$ ), it could be inferred that the biofilm-forming protein formation must have been inhibited along with other protein syntheses. The protein concentration, as expected, was also reduced after being treated with herbal extracts and antibiotics (Figure 5C). The maximum reduction of protein content was observed when treated with ethanolic extract of $C$. longa.

\subsection{Microscopic studies}

Fluorescence Microscopy: The fluorescence microscopy revealed the presence of a thick coating of biofilm in the untreated samples of Staphylococcus aureus $\&$ Pseudomonas aeruginosa. However, the herbal challenge with ethanolic extract of $C$. longa resulted in a significant reduction in the microbial attachment to the glass surface compared to controls (Figure. 6A -D). 
SEM analysis: The biofilm's topology developed by Staphylococcus aureus and Pseudomonas aeruginosa and Curcuma longa extract's effect on it.
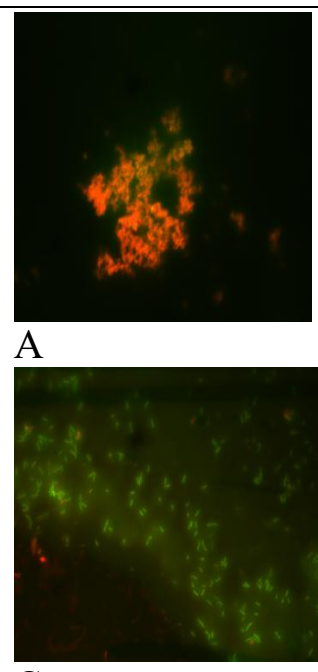

C

Fig. 6. Fluorescence microscopic images of biofilms developed by Pseudomonas aeruginosa and Staphylococcus aureus.

Fluorescence images illustrating the effect of Curcuma longa extract $(1 \mathrm{mg} / \mathrm{ml})$ on biofilm formation. A) Biofilm was established on a glass slide by Staphylococcus aureus in the absence of Curcuma longa extract. B) Biofilm was established on a glass slide by Staphylococcus aureus due to the addition of plant extract. C) Biofilm established on glass slides by Pseudomonas aeruginosa. D) Biofilm was established on a glass slide by Pseudomonas aeruginosa due to the addition of plant extract was analyzed by SEM. A well-grown biofilm along with adhering bacterial cells was observed in control (normal biofilm developed by bacterial isolate) in the SEM analysis, whereas dispersed bacterial cells were observed in treated samples (Figure 7). In the formed biofilm images, fewer colonization areas were observed due to increased spaces between the microcolonies adhered to the material. A less notable reduction in $S$. aureus cell after treatment with curcumin I
(Tyagi et al., 2015; Yue et al., 2016) was observed. On the other hand, a well-grown biofilm along with adhering bacterial cells was observed in control (normal biofilm developed by microbial samples)

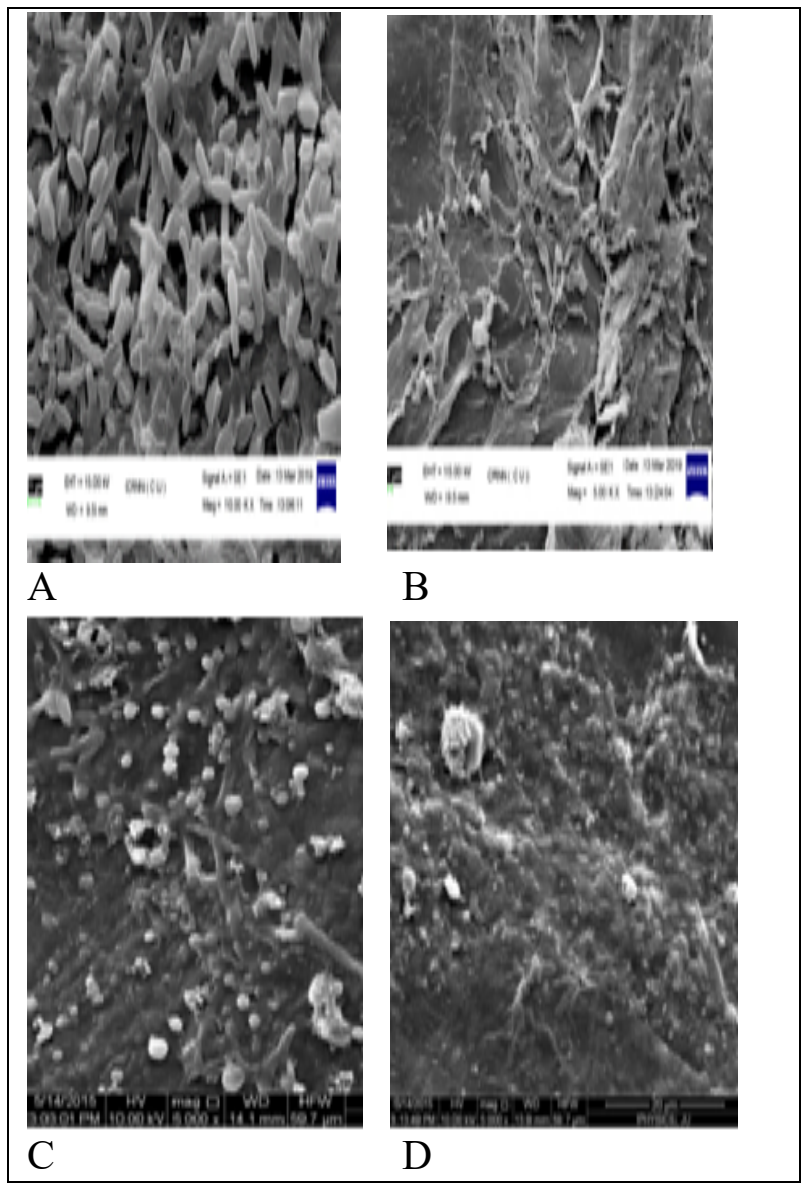

Fig. 7. SEM images of biofilms developed by Pseudomonas aeruginosa and Staphylococcus aureus.

SEM images illustrating the effect of Curcuma longa extract $(1 \mathrm{mg} / \mathrm{ml})$ on biofilm- formation. A) Biofilm established on chitin flakes by Pseudomonas aeruginosa. B) Shrinkage of the EPS matrix of Pseudomonas aeruginosa due to the addition of plant extract. C) Biofilm established on chitin flakes by Staphylococcus aureus. D) Shrinkage of EPS matrix of Staphylococcus aureus due to the addition of plant extract. 
Phytocompounds of Curcuma longa extract are more effective against bacterial biofilm than pure curcumin only: An in-vitro and

\section{FTIR Analysis}

Fourier Transform Infrared spectroscopy (FTIR) spectra of bacterial biofilm formed in the presence and absence of ethanolic plant extract (Figure 8 A \& B) had shown the bond stretching frequencies. A maximum spectral peak was found at $707 \mathrm{~cm}^{-1}, 2942$ $\mathrm{cm}^{-1}, 3462 \mathrm{~cm}^{-1}$ confirming the presence of a carboxylic group, $\mathrm{C}-\mathrm{H}$ functional groups, and hydroxyl group, respectively. Absorption bands at 3423.15 and $3420.77 \mathrm{~cm}^{-1}$ confirmed the presence of phenols and alcohols with a free $\mathrm{OH}$ group. The region of $2359.03 \mathrm{~cm}^{-1}$ indicated the presence of symmetric stretching of $\mathrm{COO}_{-}^{-}$ in solution. The bands at 2138.93, 2138.90, 1123, and $1150.67 \mathrm{~cm}^{-1}$ revealed the presence of alkynes, $\mathrm{N}-\mathrm{C}$, and $\mathrm{N}=\mathrm{C}$ groups in $\mathrm{R}-\mathrm{N}=\mathrm{C}=\mathrm{S}$ structure and the presence of carboxylic acid groups. The bands at 821.69, 674.63 , and $675.51 \mathrm{~cm}^{-1}$ represented the presence of $=\mathrm{CH}$ in aromatic compounds in the plant extract. The gradual decrease or disappearance of peaks clearly indicated the reduction of protein and carbohydrate content in the bacteria's EPS when treated with the extract of Curcuma longa.

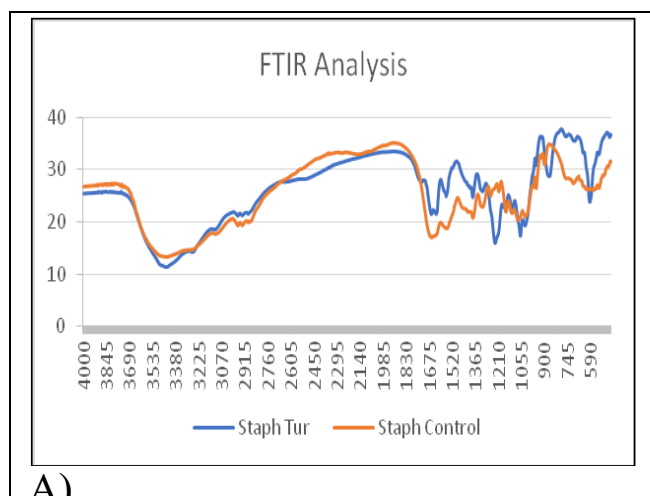

\section{Discussions}

The present study portrayed that the phenolic content was $470.32 \mu \mathrm{g} / \mathrm{ml}$ and showed higher hydrogen and hydroxyl radical scavenging activity than that of the commercially purchased curcumin. It was also found the ethanolic extract of C. longa was able to bring about maximum inhibition in the viability of the sessile cells of $S$. aureus and $P$. aeruginosa as compared to the commercially purchased curcumin and the standard antibiotic erythromycin.

Moreover, the findings indicated that the effect of the ethanolic extract of the plant had greater efficacy in removing the biofilm than the pure active compound curcumin I. Although the active ingredient curcuminoid (including curcumin, dimethoxy-curcumin, and bis-demethoxy-curcumin), being insoluble in water was as such were poorly acceptable and absorbable by the bacterial cells (Yue et al., 2016), alcoholic extract of the plant made them more accessible to bacterial membrane. Furthermore, the presence of some other minor components like turmerones in the raw plant extract other

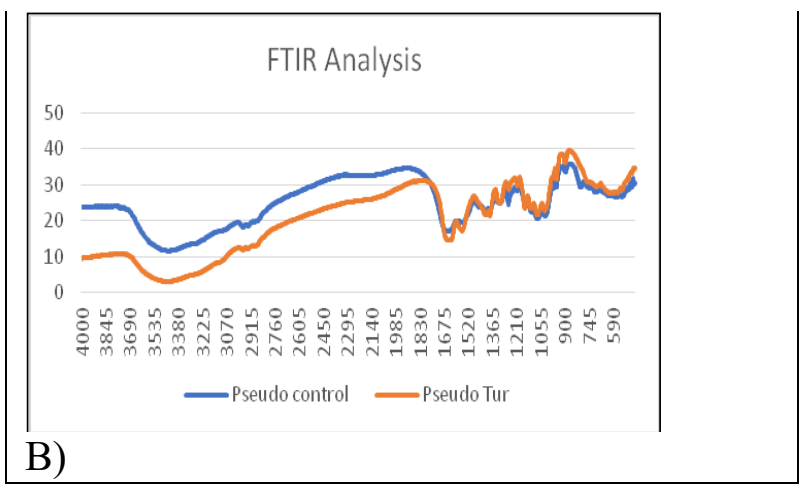

Fig. 8. A) FTIR spectra of Staphylococcus aureus biofilm in presence and absence of Curcuma longa B) FTIR spectra of Pseudomonas aeruginosa biofilm in presence and absence of Curcuma longa. 
than purified curcumin, the synergistic effect of which probably had made the ethanolic extract of $C$. longa more effective antibiofilm agent. The in-silico studies showed that the binding interaction between the biofilm-forming protein of $S$. aureus (3TIP) and $P$. aeruginosa (3ZYB) was maximum when dock synergistically with curcumin and methyl palmitate (-23.844 $\mathrm{Kcal} / \mathrm{mol}$ ), whereas curcumin and dehydrozingerone $(-17.811 \mathrm{Kcal} / \mathrm{mol})$ were much higher than the docking interaction of pure curcumin $(-11.404 \mathrm{Kcal} / \mathrm{mol})$. This also showed that curcumin's synergistic action along with other bioactive compounds like methyl palmitate and dehydrozingerone found within the ethanolic extract of $C$. longa makes it a better antibiofilm agent than the commercially purchased curcumin and standard antibiotic erythromycin.

\section{Conclusion}

To face the challenge of bacterial resistance against the conventional groups of antibiotics being used regularly, various pharmacological industries have tried to develop synthetic compounds, but this problem is still posing a burning issue. In the present study, the effect of a mixture of phytocompounds (turmeric extract), purified single phytocompound (curcumin I), and antibiotic (erythromycin) was applied on two model biofilm-forming bacterial strains, namely, $S$. aureus and $P$. aeruginosa, the results of which indicated that antibiotic could be successfully replaced by suitable phytocompound and instead of single, a mixture of phytocompounds was proved to be more effective due to the synergistic action of component compounds present in the mixture extract. Moreover, since turmeric extract as such was more costeffective than commercially available curcumin I, it could be successfully used against biofilm-forming nosocomial bacteria.
Ethical Statement The protocol of the work was approved by Institutional Ethics Committee of Maulana Abul Kalam Azad University of Technology, West Bengal (Govt of West Bengal, India) [Ref No: MAKAUT: IEC (18-19)/02, dated 30.12.2019]

\section{ACKNOWLEDGEMENTS}

The authors gratefully acknowledge the Center for Research in Nanoscience and Nanotechnology (CRNN), University of Calcutta, for SEM and Mr. Dipak Chandra Konar of Central Instrumentation facility, Bose Institute) for FTIR readings. The authors are thankful to Jyotirmoy Rakshit for helping in having the fluorescent micrographs in MAKAUT, WB.

\section{References}

Alvi, A. M.; Iqbal, N.; Bashir, M. A.; Rehmani, M. I. A.; Ullah, Z. et al. (2018) Efficacy of Rhazya stricta leaf and seed extracts against Rhyzopertha dominica and Trogoderma granarium. Kuwait Journal of Science, 45 (3): 64-71.

Arshad, M.; Ullah, M. I.; Afzal, M.; Khalid, S.; Raza, A. B. M. \& Iftikhar, Y. (2019) Evaluation of plant extracts for the management of citrus leafminer, Phyllocnistis citrella (Lepidoptera: Gracillariidae) Kuwait Journal of Science, 46 (1): 58-67.

Brunk, C. F.; Jones, K. C. \& James, T. W. (1979) Assay for nanogram quantities of DNA in cellular homogenates. Analytical Biochemistry, 92:497-500.

Charles M.V.P.; Kali, A. \& Seetha, K. S. (2016) Inhibitory Effect of Curcumin on Biofilm Produced by Bacterial Pathogens International Journal of Current Microbiology and Applied Sciences, 5(12): 692-697. 
Debiyi, O. O. \& Sofowora, F. A. (1978) Phytochemical screening of medical plants, Iloyidia, 3:234-246.

Delden, C. \& Iglewski, B. H. (1998) Emerging Infectious Diseases, 4: 551-560.

Deutscher, M. P. (1990) A Guide to Protein Purification. Methods in Enzymology, Academic Press. Pp. 182.

Ding, X.; Peng, X. J.; Jin, B.S.; Xiao, M.; Chen, J. K.; Li, B. et al. (2015) Spatial distribution of bacterial communities driven by multiple environmental factors in a beach wetland of the largest freshwater lake in China. Frontiers in Microbiology, 6(129): 19.

Fong, J.N.C. \& Yildiz, F.H. (2015) Biofilm Matrix Proteins, Microbiology Spectrum, 3(2): 1-27.

Gandhi, A. D.; Vizhi, D. K.; Lavanya, K.; Kalpana, V. N.; Devi Rajeswari. et al. (2017) In vitro anti-biofilm and antibacterial activity of Sesbania grandiflora extract against Staphylococcus aureus. Biochemistry and Biophysics Reports, 12:193-197.

Gomes F.; Teixeira P; Ceri H. \& Oliveira R. (2012) Evaluation of antimicrobial activity of certain combinations of antibiotics against in vitro Staphylococcus epidermidis biofilms. Indian Journal of Medical Research, 135: 542-547.

Gupta, S. C.; Sung, B.; Kim, J. H.; Prasad, S.; Li, S. \& Aggarwal, B. B. (2013). Multitargeting by turmeric, the golden spice: From kitchen to clinic. Molecular Nutrition and Food Research, 57(9): 1510-1528.

Hasan, M. \& Mahmud, M. (2014) The contribution of turmeric research and development In the economy of Bangladesh: an ex-post analysis. International Journal of
Agricultural Research, Innovation, and Technology, 4(1):1-10.

Hayat. S. \& Sabri A. N. (2016) Screening for antibiofilm and antioxidant potential of turmeric (Curcuma longa) extracts. Pakistan Journal of Pharmaceutical Sciences, 29(4):1163-70.

Hossain, M. A. \& Rahman, A. (2011) Chemical composition of bioactive compounds by GC-MS screening and antifungal properties of crude extracts of cabbage samples. Asian Journal of Biotechnology, 3: 68-76.

Kumar, L.; Chhibber S. \& Harjai. K. (2013) Zingerone inhibit biofilm formation and improve antibiofilm efficacy of ciprofloxacin against Pseudomonas aeruginosa PAO1. Fitoterapia, 90:73-8.

Lahiri, D.; Nag, M. \& Ray, R. R. (2018) Comparative Study of the Antibiofilm Effect of plant extracts and antibiotic on Staphylococcus aureus ATCC 0352, International Journal of basic and applied research, 8 (10): 419-427.

Li, B.; Li, X.; Lin, H. \& Zhou, Y. (2018) Curcumin as a Promising Antibacterial Agent: Effects on Metabolism and Biofilm Formation in S. mutans. Biomedical Research International, Article ID 4508709: 1-11.

Li, J.; Xie, S. \& Ahmed, S. (2017) Antimicrobial Activity and Resistance: Influencing Factors. Frontiers in Pharmacology, 8 (364) :1-11.

Li, Z. \& Nair, S.K. (2012) Quorum sensing: how bacteria can coordinate activity and synchronize their response to external signals? Protein Science, 21: 1403-1417.

López, D.; Vlamakis, H. \& Kolter, R. (2010) Biofilms. Cold Spring Harbor Perspective in Biology, 2(7): a000398. 
Meade, H. M.; Long, S. R.; Ruvkun, C. B.; Brown, S. E. \& Ausubel, F. M. (1982) Physical and genetic characterization of symbiotic and auxotrophic mutants of Rhizobium meliloti induced by transposon Tn5 mutagenesis. Journal of Bacteriology, 149:114-122.

Morris, G. M.; Goodsell, D. S.; Halliday, R. S.; Huey, R.; Hart, W. E. et al. (1998) Automated docking using a Lamarckian genetic algorithm and an empirical binding free energy function to compute its bulk and surface properties. Journal of Computational Chemistry, 19(14): 1639-1662.

Nikolić, M.; Vasić, S.; Đurđević, J.; Stefanović O. \& Čomić L. (2014) Antibacterial and antibiofilm activity of ginger (Zingiber officinale (Roscoe)) ethanolic extract. Kragujevac Journal of Science, 36: 129-136.

Nwodo, U.; Green, E., \& Okoh, A. (2012) Bacterial exopolysaccharides: functionality and prospects. International Journal of Molecular Sciences, 13(12): 14002-14015.

Raorane, C. J.; Lee, J. H.; Kim, Y. G.; Rajasekharan, S. K.; García-Contreras, R. et al. (2019) Antibiofilm and antivirulence efficacies of flavonoids and curcumin against Acinetobacter baumannii. Frontiers in Microbiology, 10:990.

Rio, D.C.; Ares Jr, M.; Hannon, G. J.\& Nilsen, T. W. (2011) Adapted from RNA: A Laboratory Manual, by CSHL Press, Cold Spring Harbor, NY, USA.

Roopashree, T. S.; Dang, R.; Rani, R. H. S. \& Narendra C. (2008) Antibacterial activity of antipsoriatic herbs: Cassia tora, Momordica charantia, and Calendula officinalis. International Journal Applied Research in Natural Products, 1(3): 20-28.

Sarkar, R.; Chaudhary, S. K.; Sharma, A.; Yadav, K. K.; Nema, N. K. et al. (2014) Anti-biofilm activity of Marula- a study with the standardized bark extract. Journal of Ethnopharmacology, 154: 170175.

Tang, H.J.; Chen, C.C.; Ko, W.C.; Yu, W. L.; Chiang, S. R.\& Chuang, Y. C. (2011) In-vitro efficacy of antimicrobial agents against high-inoculum or biofilm embedded methicillin-resistant Staphylococcus aureus with vancomycin minimal inhibitory concentrations equal to $2 \mu \mathrm{g} / \mathrm{ml}$ (VA2MRSA). International Journal of Antimicrobial Agents, 38(1):46-51.

Teanpaisan, R.; Kawsud, P.; Pahumunto, N. \& Puripattanavong, J. (2016) Screening for antibacterial and antibiofilm activity in Thai medicinal plant extracts against oral microorganisms, Journal of Traditional and Complementary Medicine, 7(2): 172-177.

Teow, S.Y.; Liew, K.; Ali, S. A.; Khoo, A. S. \& Peh, S. C. (2016) Antibacterial Action of Curcumin against Staphylococcus aureus: A Brief Review. Journal of Tropical Medicine, Article ID 2853045: 1-10.

Tyagi, P.; Singh, M.; Kumari, H.; Kumari, A. \& Mukhopadhyay, K. (2015) Bactericidal Activity of Curcumin I is Associated with Damaging of Bacterial Membrane. PLOS ONE, 10(3): e0121313.

Yang, Y.H.; Lee, T.H.; Kim, J. H.; Kim, E. J.; Joo, H.S. et al. (2006) Highthroughput detection method of quorumsensing molecules by colorimetry and its applications. Analytical Biochemistry, 356(2): 297-299.

Yue, G. G. L.; Jiang, L.; Wok, H. F.; Lee, J. K. M.; Chan, K. M. et al. C.B.S. (2016) Turmeric ethanolic extract possesses stronger inhibitory activities on colon tumor growth than curcumin - The importance of turmerones. Journal of Functional Foods, 22: 565-577. 
Phytocompounds of Curcuma longa extract are more effective against bacterial biofilm than pure curcumin only: An in-vitro and in-silico analysis

$\begin{array}{ll}\text { Submitted } & : 01 / 09 / 2019 \\ \text { Revised } & : 15 / 04 / 2020 \\ \text { Accepted } & : 15 / 04 / 2020 \\ \text { DOI } & : 10.48129 / \text { kjs.v48i2.8310 }\end{array}$

